\title{
THE FACTORS AFFECTING LABOR DEMAND IN THE FOOD AND TOBACCO INDUSTRY IN NORTH SUMATERA PROVINCE
}

\author{
Sari Wulandari $\left.{ }^{*}\right)$, Sari Fajar Ayu ${ }^{2}$ \\ ${ }^{1 *}$ Postgraduate Program, Universitas Negeri Medan \\ ${ }^{2}$ Faculty of Economics and Business, Universitas Sumatera Utara \\ Email: sariwulandari@yahoo.com
}

\begin{abstract}
Labor demand in North Sumatra during the period 1991 to 2012 showed a fluctuating condition, where in 2001 is decline. This research aims to analyze the influence of the investment sector, the number of industries, the regional minimum wage and inflation on labor demand sectors of the food industry, beverages and tobacco in North Sumatra Province simultaneously and partially. The data used are secondary data source from Statistics Indonesia of North Sumatra Province namely variable investment industry, the number of industries, the minimum wage, inflation and labor amount of food beverages and tobacco industry in North Sumatra province in the time series from 1991 till 2012 Data analysis wasper formed using OLS (Ordinary Least Square) with multiple linear regression models estimated with the help of the program E-views 7 . The results of this study simultaneously changes in industry investment variables, the number of industries, $R M W$, and inflation significantly influence demand labor sector food industry, beverages and tobacco in North Sumatra Province. While partially concluded that the investment variable number of industry sectors and industries and a significant positive effect, negative effect variables and minimum significant wage, while the inflation variable and no significant negative effect on the demand for labor in the industrial sector of food, beverages and tobacco in North Sumatra Province. The results of this study also showed that the most dominant variable effect on labor demand sectors of the food industry, beverages and tobacco in North Sumatra Province is the minimum wage.
\end{abstract}

Key words: Labor, Investment Industry Sector, Industry Number, RMW, Inflation and Food Industry Beverages and Tobacco.

\section{INTRODUCTION}

ong-term economic development, followed by income growth, will bring about
a fundamental change in the economic structure, namely a shift from a
traditional economy with agriculture as the main sector to a modern economy dominated by non-primary sectors such as the industrial sector. The manufacturing industry sector is a sector engaged in processing raw materials or processing raw materials which has labor absorption which can add value added to economic growth in North Sumatra Province. The classification of large and medium industries generates a greater contribution to GRDP than the classification of small and micro industries. However, the classification of small and micro industries results in greater absorption of 
labor than the classifications of large and medium industries. The classification of large and medium industries in the food, beverage and tobacco industry provides the largest contribution, especially in North Sumatra Province. This can be seen from the large number of food, beverage and tobacco industries in the province of North Sumatra, for example in the 2010 s.d. 2012 as follows:

Table 1: Number of Large and Medium Industrial Companies by Industry Group 2010-2012

\begin{tabular}{|c|c|c|c|c|}
\hline & Industrial Classification & 2010 & 2011 & $2012^{\mathrm{e})}$ \\
\hline \multicolumn{2}{|r|}{ (1) } & $(2)$ & (3) & (4) \\
\hline 1. & Manufacture of Food, Beverage and Tobacco & 447 & 460 & 462 \\
\hline 2. & Manufacture of Textiles, Clothing and Leather & 54 & 45 & 45 \\
\hline 3. & Manufacture of Wood, Including Furniture & 115 & 117 & 118 \\
\hline 4. & Manufacture of Paper, Printing and Publishing & 27 & 30 & 30 \\
\hline 5. & $\begin{array}{l}\text { Manufacture of Chemicals, Petroleum, Coal, Rubber and } \\
\text { Plastics }\end{array}$ & 189 & 189 & 190 \\
\hline 6. & Manufacture of Non Metalic, Except Petroleum and Coal & 57 & 56 & 56 \\
\hline 7. & Manufacture of Basic Metals & 18 & 12 & 12 \\
\hline 8. & $\begin{array}{l}\text { Manufacture of Fabricated Metal Products, Machinery and } \\
\text { Equipment }\end{array}$ & 82 & 59 & 59 \\
\hline \multirow[t]{2}{*}{9.} & Other Manufacturing Industries & 13 & 39 & 39 \\
\hline & Total & 1002 & 1007 & 1012 \\
\hline
\end{tabular}

Source: Statistics Indonesia of North Sumatra Province

From Table 1 it can be seen that the number of food, beverage and tobacco industries with a total number of large and medium industries in North Sumatra Province, in 2012 was bigger than other industries, namely 462 companies or as much as 45.65 percent of the total number of large and medium industries which reached 1,012 companies. So that it can be stated that the food, beverage and tobacco industry groups are the leading sectors that produce a greater contribution to GRDP than the other 8 large and medium industrial groups. For more details on the development of the food, beverage and tobacco industry with large and medium industries in North Sumatra Province, it can be seen from the following figure:

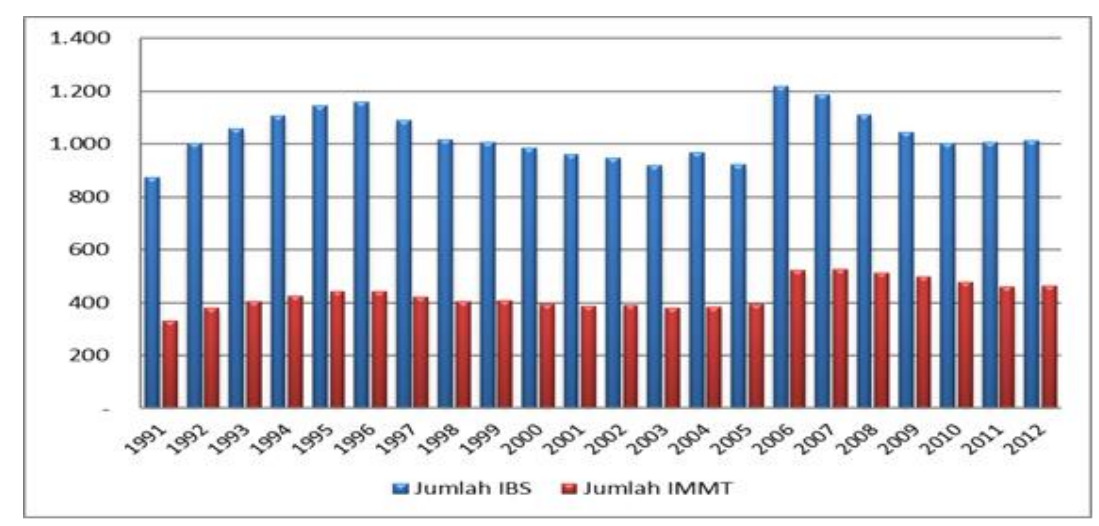

Figure 1: Development of the Amount of IBS and the Food, Beverage and Tobacco Industry in North Sumatra from 1991 to. 2012

Source: Processed data from Statistics Indonesia of North Sumatra Province 
Judging from its natural resources, the North Sumatra Province has a very large opportunity for investment activities, both Foreign investment (FI) and Domestic Investment (DI), especially from the industrial sector. This is due to the availability of various raw materials from agricultural, plantation, fishery and livestock products, all of which can be used for the development of the manufacturing industry sector, many of which are large and medium-sized industries, especially in the food, beverage and tobacco industries.

Based on previous research by Prihartanti (2007) entitled "Factors Affecting Industrial Manpower in Bogor City", the variables that influence labor demand include wages, investment, real GRDP, number of business units and crises. As for the development of the number of workers in the food, beverage and tobacco industry (in people), the number of food, beverage and tobacco industries (in companies), inflation (in percent), investment in the industrial sector (in rupiah) and UMR (in rupiah) in North Sumatra 1991-2012 is shown in the following table.

Furthermore, if the development of the number of industries is related to the number of industrial workers in the food, beverage and tobacco sector. Ideally, the greater the number of industries in the food, beverage and tobacco sector, the greater the development of the workforce. Based on data from Statistics Indonesia of North Sumatra Province (2011) the decline in the number of industries in the food, beverage and tobacco sectors was also followed by a decrease in the number of workers. For example, in 1997, the decline in the number of industries by 5 percent as a result of the monetary crisis in North Sumatra Province also resulted in a decrease in the number of industrial workers in the food, beverage and tobacco sectors.

However, it turns out that not all fluctuations in the number of industries are followed by fluctuations in the number of workers. This can be observed, for example, in 1995, an increase in the number of industries by 4 percent was followed by a decrease in the number of workers in the food, beverage and tobacco sector by 4 percent. This indicates an inconsistency in the increase in the number of food, beverage and tobacco sectors with the growing number of large and medium industrial workers in the food, beverage and tobacco sector in the province of North Sumatra.

Based on the table above, it can be seen that the development of the number of workers in the food, beverage and tobacco industry has fluctuated. The highest decline in the number of industrial workers occurred in 2001, which fell 13 percent from the previous year or decreased by 8,383 workers. Meanwhile, the highest increase in the number of workers in the food, beverage and tobacco sector occurred in 1992, namely an increase of 12.25 percent from the previous year or an increase of 7,667 workers. (Statistics Indonesia of North Sumatra Province, 2012) 
Table 2: Development of the Number of Food, Beverage and Tobacco Industries

(NFBTI), Number of Food, Beverage and Tobacco Industry Workers (NFBTIW), Industrial Sector Investment (ISI), Regional Minimum Wages (RMW), and Inflation (INF) North Sumatra T.A. 1991 to 2012

\begin{tabular}{|c|c|c|c|c|c|c|c|c|c|c|}
\hline $\mathrm{BS}$ & JI & 70 & $\mathbf{K}$ & $\%$ & V & $\%$ & IR & $\%$ & $\mathrm{NF}$ & $\%$ \\
\hline 1991 & 331 & & & & & . & & & 99 & \\
\hline 92 & 99 & & & 12,25 & & & & & 56 & $(49,28$ \\
\hline 93 & 405 & & & & & & & & 9,75 & \\
\hline 94 & 426 & & 6 & & & & & & 8,28 & \\
\hline 95 & 443 & & & & & & & & 28 & $(12,08)$ \\
\hline 1996 & 443 & & 534 & & & & & & 7,24 & $(0,55)$ \\
\hline 997 & 422 & ,74) & 861 & $(2,51)$ & 4 & & & 42 & 17,05 & 135,50 \\
\hline 1998 & 403 & 50) & 7 & & & & & & 83,56 & 390,09 \\
\hline 1999 & 407 & & 4 & & & & & & 1,37 & $(98,36)$ \\
\hline 0 & 393 & & & & & & & & 5,73 & 318,25 \\
\hline 2001 & 385 & 04) & 55.081 & $(13,21)$ & & & & 06 & 14,79 & 158,12 \\
\hline 02 & 388 & & 2 & & & & & & 9,59 & $(35,16)$ \\
\hline 03 & 379 & 32) & 56 & & 0 & 551 & & & 23 & $(55,89)$ \\
\hline 2004 & 384 & & 57 & & & & & & 6,80 & 60,76 \\
\hline 2005 & 394 & & 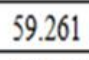 & & & & & & 22,41 & 229,56 \\
\hline 2006 & 521 & 3223 & 63.978 & 7,96 & 2.709 .30 & & & & 6,11 & $(72,74$ \\
\hline 2007 & 525 & & & & & & & & & 8,02 \\
\hline 2008 & 512 & & 62.5 & $(4,14)$ & 3.186. & & & 8,04 & 10,72 & 62,42 \\
\hline 2009 & 498 & & 60.20 & $(3,69)$ & 794.960 & 06) & & 10,07 & 2,61 & $(75,65)$ \\
\hline 2010 & 469 & & 58.248 & $(3,25)$ & 1.463 .500 . & & & & 8,00 & 206,51 \\
\hline 2011 & 460 & $(1,92)$ & 64.991 & 11,58 & & 211,86 & & 7,31 & 3,67 & $(54,13)$ \\
\hline 2012 & 462 & 0,43 & 66.031 & 1,60 & 5.063 .968 .995 .000 & 10,95 & 1.200 .000 & 15,89 & 3,86 & 5,18 \\
\hline
\end{tabular}

Source: Statistics Indonesia of North Sumatra Province

Changes in the ups and downs of IBS's workforce in the food, beverage and tobacco sector are of course influenced by other factors. If the number of IBS in the food, beverage and tobacco sector is related to investment in the industrial sector, it can be seen that the higher the investment tendency, the more the number of IBS in the food, beverage and tobacco sector will increase. Increased investment will increase capital for the development of new industries. The increase in investment in the industrial sector will certainly increase the government's capital to develop industrial sectors, so that to achieve all these goals it requires the absorption of more and more workers. Based on data from Statistics Indonesia of North Sumatra Province (2011) in 1992, an increase in investment of 39.01 percent was in line with the increase in the number of IBS workers in the food, beverage and tobacco sector by 12.25 percent. However, it turns out that not all fluctuations in investment are followed by ups and downs in the number of industrial workers. This can be observed, for example, in 2004, the decline in investment in the industrial sector that year was 67.59 percent, followed by an increase in the number of industry in the food, beverage and tobacco sector by 2.57 percent. This shows 
the inconsistency of investment theory with reality. Then, if the total labor demand in the food, beverage and tobacco sector is linked to inflation, it can be seen that there is a tendency for high inflation to cause a decrease in the number of workers in the food, beverage and tobacco sector industries. The increase in inflation causes all industrial production costs to increase, while the purchasing power of the people decreases. Of course this will make it difficult for the industry to develop, even to overcome this problem is often pursued by reducing the workforce in order to streamline all expenses and maximize profits. However, it turns out that not all increases in inflation are accompanied by a decline in developments in the number of industrial workers. Based on data from Statistics Indonesia of North Sumatra Province (2011) in 1998, a drastic increase in inflation in that year by 390 percent, was actually followed by an increase in the number of industrial workers by 0.93 percent. This indicates an inconsistency in inflation with developments in the number of workers in the food, beverage and tobacco sectors. From the above phenomenon, it is known that there is a mismatch between the theory related to the demand for the number of workers in the food, beverage and tobacco industry, namely the number of industries, investment in the industrial sector, RMW and inflation with the reality in the field. This is certainly an interesting study considering the food, beverage and tobacco industries are the leading sectors of 9 industrial sectors in North Sumatra.

Furthermore, it needs to be realized that the demand for labor in the food, beverage and tobacco industry does not only concern problems in the economic sector, but also problems in the social sector, especially inflation during the past economic crisis. The problem of labor demand is not only about the availability of investment, especially investment in the industrial sector, but also the question of whether the existing employment opportunities are sufficient to provide decent services for workers. Based on the data above, which includes the absorption of labor in the food, beverage and tobacco industry in North Sumatra, such as investment in the industrial sector, RMW, the number of food, beverage and tobacco industries, and inflation.

\section{RESEARCH METHOD}

This study uses secondary data with time series data types during the period (19912012). With the data used comes from Statistics Indonesia. The data required include the number of workers in the food, beverage and tobacco industry in units of life, the number of food, beverage and tobacco industries in company units, inflation in percent, and investment in the industrial sector in units of billions of rupiah in North Sumatra Province.

The analysis used is econometric analysis using the Ordinary Least Square (OLS) method. The OLS method has the ability to analyze the effect of several independent variables on the dependent variable, because OLS has the Best Linear Unavailable Estimator (BLUE) property.

This regression analysis uses an estimation model based on several independent variables, namely industrial sector investment (ISI), the number of food and beverage 
and tobacco industries (NFBTI), RMW, inflation (INF). The functions of the number of workers in the food and beverage and tobacco industry (NFBTIW) are:

$$
\mathrm{NFBTIW}=\left.\left.\boldsymbol{\beta}_{0} * I S\right|^{\beta 1} * \mathrm{NFBT}\right|^{\beta 2} * \mathrm{RMW}^{\beta 3} * \mathrm{INF}^{\beta 4}
$$

Considering that the variable numbers in question have relatively large numbers, the model is formulated into a logarithmic form, so the estimation model used is as follows:

\section{$\log$ NFBTIW $=\beta_{0}+\beta_{1} \log I S I+\beta_{2} \operatorname{LogNFBTI}-\beta_{3} \operatorname{LogRMW}-\beta_{4} \operatorname{LogINF}+e \ldots .$.}

Where :

NFBTIW = Number of Food, Beverage and Tobacco Industry Workers (person)

ISI = Industrial Sector Investment (Million Rupiah)

NFBTI = Development of the Number of Food, Beverage and Tobacco Industries (Industry)

RMW = Regional Minimum Wages (Rupiah)

INF $\quad=$ Inflation (Percent)

$\varepsilon \quad=$ Stochastic Term Error

Log = Logarithm

$\beta_{0}-\beta_{5} \quad=$ Constant

The data that has been collected will be presented in tabular form and analyzed using descriptive methods. The estimation model that has been shown previously will be regressed to see the effect between the independent variables and the dependent variable with the Eviews 7 package

\section{RESULT AND DISCUSSION}

Development of the Food, Beverage and Tobacco Sector Workforce in North Sumatra Province

Table 3: Food, Beverage and Tobacco Sector Workers in North Sumatra Province 19912012 (Normal Tabulation in Person)

\begin{tabular}{|c|c|c|}
\hline OBS & NFBTIW & Percentage \\
\hline 1991 & 62.576 & 12,25 \\
\hline 1992 & 70.243 & 0,69 \\
\hline 1993 & 70.727 & $-1,73$ \\
\hline 1994 & 69.506 & $-4,12$ \\
\hline 1995 & 66.642 & $-0,16$ \\
\hline 1996 & 66.534 & $-2,51$ \\
\hline 1997 & 64.861 & 0,93 \\
\hline 1998 & 65.467 & 0,18 \\
\hline 1999 & 65.584 & $-3,23$ \\
\hline 2000 & 63.464 & $-13,21$ \\
\hline 2001 & 55.081 & 2,18 \\
\hline 2002 & 56.281 & 0,37 \\
\hline 2003 & 56.492 & 2,57 \\
\hline 2004 & 57.943 & 2,27 \\
\hline 2005 & 59.261 & \\
\hline
\end{tabular}




\begin{tabular}{|c|c|c|}
\hline 2006 & 63.978 & 7,96 \\
\hline 2007 & 65.216 & 1,94 \\
\hline 2008 & 62.513 & $-4,14$ \\
\hline 2009 & 60.206 & $-3,69$ \\
\hline 2010 & 58.248 & $-3,25$ \\
\hline 2011 & 64.991 & 11,58 \\
\hline 2012 & 66.031 & 1,60 \\
\hline
\end{tabular}

Source: Statistics Indonesia of North Sumatra Province (Processed)

The number of industrial workers in the food, beverage and tobacco sector that occurs in Prov. North Sumatra tends to fluctuate and tend to decline. The highest number of workers actually occurred in 1993, namely 70,243 workers. Meanwhile, the lowest number of workers actually occurred in 2001, namely 55,081 workers. Furthermore, the highest increase in the number of workers in the food, beverage and tobacco sector occurred in 1992 with 7,667 people from the previous year (1991) from 62,576 people to 70,243 people. Meanwhile, the lowest growth in the food, beverage and tobacco sector was in 2001, amounting to 8,383 people or a decrease of 13.21 percent from the previous year (2000).

\section{The Development of Industrial Sector Investment in North Sumatra Province}

Investment in this industrial sector is influenced by two things, namely the realization of domestic investment (DI) and foreign investment (FI). The fluctuation of investment cannot be separated from the government's role in maintaining the investment climate, such as security, political stability, eliminating extortion practices and a convoluted bureaucratic system. If this continues to happen, it will reduce the interest of both domestic and foreign investors. In 2012, investment in the industrial sector in North Sumatra was recorded at 5.06 trillion. When compared with the beginning of the research year, it means that there has been an increase of 1,749.5 percent or a rapid increase of 4.79 trillion from 1991. The development of industrial sector investment in North Sumatra Province during the 1991-2012 research year was as follows:

Table 3: Investment in the Industrial Sector in North Sumatra Province 1991-2012

(Normal Tabulation in Rupiah)

\begin{tabular}{|c|c|c|}
\hline OBS & ISI & Percentage \\
\hline 1991 & 273.800 .000 .000 & 39,01 \\
\hline 1992 & 380.600 .000 .000 & 44,66 \\
\hline 1993 & 550.560 .000 .000 & 4,22 \\
\hline 1994 & 573.810 .000 .000 & 31,95 \\
\hline 1995 & 757.120 .000 .000 & $-38,82$ \\
\hline 1996 & 463.210 .000 .000 & $-0,05$ \\
\hline 1997 & 462.990 .000 .000 & 130,23 \\
\hline 1998 & 1.065 .950 .000 .000 & $-59,63$ \\
\hline 1999 & 430.280 .000 .000 & 111,60 \\
\hline 2000 & 910.490 .000 .000 & $-82,39$ \\
\hline 2001 & 160.380 .000 .000 & \\
\hline
\end{tabular}

QE Journal | Vol.09 - No.02 - 56 


\begin{tabular}{|c|c|c|}
\hline 2002 & 274.250 .000 .000 & 71,00 \\
\hline 2003 & 4.529 .520 .000 .000 & $1.551,60$ \\
\hline 2004 & 1.468 .180 .000 .000 & $-67,59$ \\
\hline 2005 & 1.737 .250 .000 .000 & 18,33 \\
\hline 2006 & 2.709 .300 .000 .000 & 55,95 \\
\hline 2007 & 2.965 .550 .000 .000 & 9,46 \\
\hline 2008 & 3.186 .990 .000 .000 & 7,47 \\
\hline 2009 & 794.960 .000 .000 & $-75,06$ \\
\hline 2010 & 1.463 .500 .000 .000 & 84,10 \\
\hline 2011 & 4.564 .026 .580 .000 & 211,86 \\
\hline 2012 & 5.063 .968 .995 .000 & 10,95 \\
\hline
\end{tabular}

Source: Statistics Indonesia of North Sumatra Province (Processed)

The number of industrial sector investments that occur in North Sumatra Province continues to experience fluctuations from year to year. The highest percentage increase occurred in 2003 amounting to 1551.60 percent or an increase of 4.255 billion from the previous year. Meanwhile, the lowest decline in the percentage of investment in the industrial sector occurred in the following year, namely 2009 amounting to 75.06 percent or a decrease of 2,392 billion from the previous year. The highest amount of investment in the industrial sector occurred in 2012 amounting to 5.063 .96 billion, while the lowest amount of investment in the industrial sector occurred in 2001 at 160.38 billion.

\section{Development of Number of Industry in the Food, Beverage and Tobacco Sector in North Sumatra Province}

The developments in the number of industries in the food, beverage and tobacco sector during the 1991-2012 research year were as follows:

Table 4: Number of FBT Industry in North Sumatra Province 1991-2012 (Normal

Tabulation within the Company)

\begin{tabular}{|c|c|c|}
\hline OBS & NFBTI & Percentage \\
\hline 1991 & 331 & 14,50 \\
\hline 1992 & 379 & 6,86 \\
\hline 1993 & 405 & 5,19 \\
\hline 1994 & 426 & 3,99 \\
\hline 1995 & 443 & 0 \\
\hline 1996 & 443 & $-4,74$ \\
\hline 1997 & 422 & $-4,50$ \\
\hline 1998 & 403 & 0,99 \\
\hline 1999 & 407 & $-3,44$ \\
\hline 2000 & 393 & $-2,04$ \\
\hline 2001 & 385 & 0,78 \\
\hline 2002 & 388 & $-2,32$ \\
\hline 2003 & 379 & 1,32 \\
\hline 2004 & 384 & 2,60 \\
\hline 2005 & 394 & 32,23 \\
\hline 2006 & 521 & 1 \\
\hline
\end{tabular}




\begin{tabular}{|l|c|c|}
\hline 2007 & 525 & 0,77 \\
\hline 2008 & 512 & $-2,48$ \\
\hline 2009 & 498 & $-2,73$ \\
\hline 2010 & 469 & $-5,82$ \\
\hline 2011 & 460 & $-1,92$ \\
\hline 2012 & 462 & 0,43 \\
\hline
\end{tabular}

Source: BPS North Sumatra Province (Processed)

The number of industries in the food, beverage and tobacco sector in North Sumatra is relatively fluctuating. The highest number occurred in 2007, reaching 525 companies, while the lowest number occurred in 1991, namely 331 companies. After the monetary crisis, the number of industrial companies in the food, beverage and tobacco sector tended to decline until 2006 at its peak. The highest decline in the number of food, beverage and tobacco sectors was in 2010, namely 29 companies, while the highest percentage growth occurred in 2006, namely an increase of 127 companies or an increase of 32.23 percent from the previous year (2005) which amounted to 394 companies.

\section{Development of Inflation in North Sumatra Province}

Inflation causes an increase in the price of goods and an increase in the price of labor wages. On the other hand, a decrease in people's purchasing power, especially those with fixed income, will result in not all materials being sold out. A high inflation rate affects the level of domestic production, weakening the production of export goods. High inflation rates reduce production because prices become high and demand for goods decreases so that production decreases. In 2012, inflation in North Sumatra was recorded at 3.86 percent. When compared with the beginning of the research year, it means that it has decreased by 57.06 percent from 1991. This development is considered good, even though in real terms there are so many differences in price conditions in 1991 with 2012, this is also due to the impact of the ebb and flow of economic development in Indonesia, especially during the peak period of the monetary crisis in 1998, when inflation reached 83.56 percent. The graph of the development of the percentage of inflation in North Sumatra Province during the research observation year 1991-2012 is as follows:

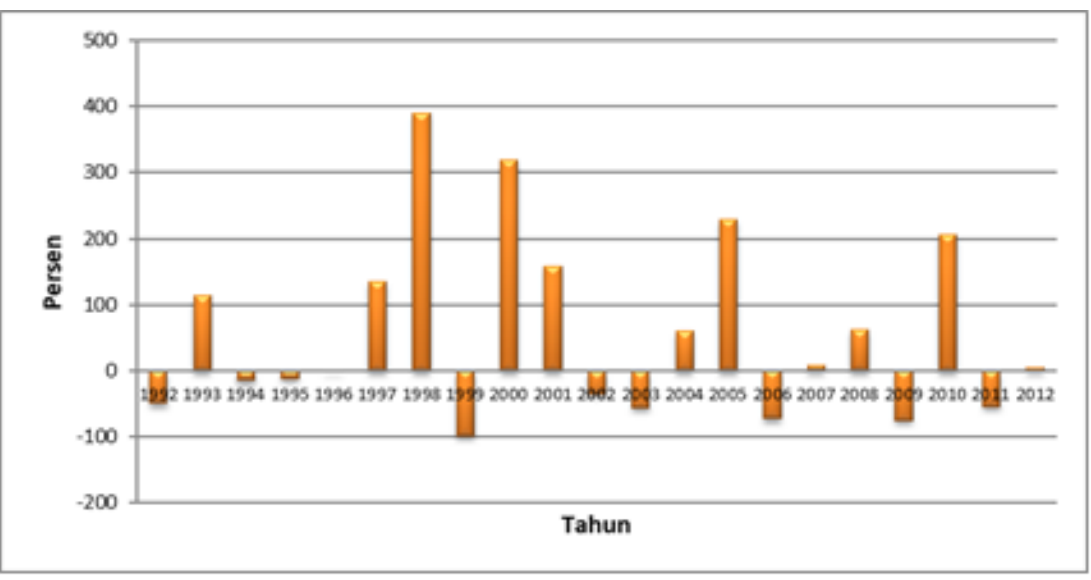

Figure 2: Inflation in North Sumatra Province 1991-2012

QE Journal | Vol.09 - No.02 - 58 


\section{Development of RMW in North Sumatra Province}

The number of Regional Minimum Wages that occurred in North Sumatra Province continues to increase from year to year. The highest increase occurred in 2002 amounting to 36.27 percent from the previous year (2001) amounting to Rp. 340,500, to Rp. 464,000, - in 2002. While the lowest RMW growth occurred in 2007 at 4.76 percent or an increase of Rp. 23,206, - from the previous year to Rp. 761,000, -.

Table 5: North Sumatra Province UMR 1991-2012 (Normal Tabulation in Rupiah)

\begin{tabular}{|c|c|c|}
\hline OBS & RMW & Percentage \\
\hline 1991 & 57.900 & - \\
\hline 1992 & 67.500 & 16,58 \\
\hline 1993 & 93.000 & 37,78 \\
\hline 1994 & 112.500 & 20,97 \\
\hline 1995 & 126.500 & 12,44 \\
\hline 1996 & 138.000 & 9,09 \\
\hline 1997 & 151.000 & 9,42 \\
\hline 1998 & 174.000 & 15,23 \\
\hline 1999 & 210.000 & 20,69 \\
\hline 2000 & 254.000 & 20,95 \\
\hline 2001 & 340.500 & 34,06 \\
\hline 2002 & 464.000 & 36,27 \\
\hline 2003 & 505.000 & 8,84 \\
\hline 2004 & 537.000 & 6,34 \\
\hline 2005 & 600.000 & 11,73 \\
\hline 2006 & 737.794 & 22,97 \\
\hline 2007 & 761.000 & 3,15 \\
\hline 2008 & 822.205 & 8,04 \\
\hline 2009 & 905.000 & 10,07 \\
\hline 2010 & 965.000 & 6,63 \\
\hline 2011 & 1.035 .500 & 7,31 \\
\hline 2012 & 1.200 .000 & 15,89 \\
\hline
\end{tabular}

Source: Statistics Indonesia of North Sumatra Province (Processed)

From the table above, it can be seen that the Regional Minimum Wage in 2012 was IDR 1,200,000 with a percentage of 15.89 percent when compared to the percentage in 1993 which was 37.78 with a Regional Minimum Wage of IDR 93,000. It can be seen that a high RMW is not necessarily a high percentage.

Variable Industrial Sector Investment Against Labor Demand in the Food Beverage and Tobacco Industry, North Sumatra Province

Variable Industrial Sector Investment turns out to have a positive and significant relationship to the demand for labor in the food, beverage and tobacco sector in North Sumatra Province. This is in accordance with the initial hypothesis of the study.

The increase in demand for industrial labor in the food, beverage and tobacco sector in North Sumatra was due to changes in increased investment in the industrial sector. The results of this study reveal that every 1 percent increase in investment in the industrial

QE Journal | Vol.09 - No.02 - 59 
sector will increase the amount of labor demand in the food, beverage and tobacco sector in North Sumatra Province by 0.0373 percent.

The results of this study support the results of previous research, Lubis (2007: 83) in the title of his Thesis "Analysis of the factors that influence job opportunities in medium and large industries in North Sumatra Province. From the results of this study, it was found that investment had a positive effect on employment in the Medium and Large Industry sector in North Sumatra Province.

In addition, in line with the results of previous research Luthfi (2011: 74) conducted a study entitled "Analysis of Determinants of Job Opportunities in the Industrial Sector in North Sumatra". The results of this study indicate that investment in the industrial sector has a positive influence on job opportunities in North Sumatra.

Prihartanti (2007: 89) in his research on "factors that influence employment in the industrial sector in the city of Bogor" concludes that investment has a positive effect on labor absorption. This shows that any increase in the investment variable will increase employment in the industrial sector in the city of Bogor.

Not only that, the results of this study also support previous research. Donna (2011: 69) conducted a study entitled "The Effect of Economic Growth, Investment, Provincial Minimum Wages and the Economic Crisis on Job Opportunities in North Sumatra". Partially it is concluded that investment has a positive and significant effect on job opportunities in North Sumatra.

This shows that the growth in the amount of investment each year is in line with the demand for labor in the food, beverage and tobacco sector in North Sumatra. This can be understood as an increase in investment in the industrial sector of a region, which will activate the economic sectors of a region. This increase in investment is also inseparable from the government's role in maintaining a good investment climate in the area, especially in North Sumatra, such as security, political stability, eliminating extortion practices and a convoluted bureaucratic system. If this continues to happen, it will reduce the interest of both domestic and foreign investors.

This increase in investment will provide a good domino effect for the community, such as an increase in the number of industries in line with the demand for labor which will automatically reduce unemployment and poverty, besides that the establishment of an industry will revive the economic activities of the community around the industry, such as restaurants. , self-service, rental homes and so on.

Therefore, the results of this study indicate that the higher the investment in the industrial sector of a region will increase the demand for labor in the food, beverage and tobacco sector in North Sumatra Province.

Variable Number of Food Beverage and Tobacco Industry Against Labor Demand in the Food Beverage and Tobacco Industry of North Sumatra Province

The variable number of industries in the food, beverage and tobacco sector has a positive and significant relationship to the demand for labor in the food, beverage and

QE Journal | Vol.09 - No.02 - 60 
tobacco sector in North Sumatra Province. This is in accordance with the initial hypothesis of the study.

The increase in labor demand in the food, beverage and tobacco sector in North Sumatra was due to changes in the increasing number of industries in the food, beverage and tobacco sector. The results of this study reveal that every increase in the number of food, beverage and tobacco sector industries by 1 percent, it will increase the amount of labor demand in the food, beverage and tobacco sector in North Sumatra Province by 0.3882 percent.

This supports the results of previous research, Prihartanti (2007: 89) in his research on "Factors Affecting the Absorption of Industrial Sector Labor in the City of Bogor" concluded that the number of business units had a positive effect on labor absorption. This shows that any increase in the number of businesses variable will increase employment in the industrial sector in the city of Bogor.

Furthermore, the results of this study also support previous research, Karo-karo (2009: 84) examines a study entitled "Analysis of the Labor Market in North Sumatra". The results of this study conclude that the number of large and medium industries has a positive effect on labor demand.

This shows that the development of the number of food, beverage and tobacco sector industries each year is in line with the demand for labor in the food, beverage and tobacco sector in North Sumatra each year. It is understandable that the increasing number of industries in the food, beverage and tobacco sector will boost demand for labor. The large number of industries is concrete evidence in efforts to equalize and absorb labor, so that the number of unemployed can be reduced in line with a reduction in the poverty rate.

Therefore, the results of this study indicate that the more the number of food, beverage and tobacco sectors in a region will increase the demand for labor in the food, beverage and tobacco sector in North Sumatra Province.

\section{Variable Inflation Against Labor Demand in the Food Beverage and Tobacco Industry, North Sumatra Province}

Variable Inflation turns out to have a negative but insignificant relationship to the demand for labor in the food, beverage and tobacco sector in North Sumatra Province. There are several things that are thought to have influenced it, namely the movement of inflation fluctuations which is quite slowly being felt by the public, so that this can be anticipated and made adjustments by the company so that the company can continue to run without any massive layoffs. However, if this inflation rises significantly, it is expected that it will have a significant impact on employment.

The results of this study support the results of previous research, Luthfi (2011: 74) conducted a study entitled "Analysis of Determinants of Job Opportunities in the Industrial Sector in North Sumatra". The results of this study indicate that inflation has a negative effect on employment opportunities in North Sumatra. 
In addition, in line with the results of previous research, Siringo-ringo (2007: 83) conducted a study entitled "Analysis of Factors Affecting Job Opportunities in Medium and Large Industries in North Sumatra Province". The results of this study indicate that partially inflation has a negative and significant effect on employment opportunities.

This supports the results of previous research, Prihartanti (2007: 89) in his research on "Factors Affecting the Absorption of Industrial Sector Labor in Bogor City" concluded that inflation has a negative effect on labor absorption. This shows that every time there is an increase in inflation, it will reduce the absorption of labor in the industrial sector in Bogor City.

The development of inflation every year is inversely proportional to the demand for labor each year. This can be understood, rising inflation will result in continuous prices and increase the company's production costs, which in turn will increase the production costs of business actors. The increase in price will certainly have an impact on decreasing people's purchasing power which may reduce consumption of certain foods, beverages and tobacco. Increasing production costs and decreasing people's purchasing power, of course, this situation will certainly encourage entrepreneurs to reduce the use of labor with other relatively more expensive inputs in order to maintain maximum profits.

Therefore, the results of this study indicate that the higher the inflation rate of a region, the lower the demand for labor in the food, beverage and tobacco sector in North Sumatra Province.

\section{Variable RMW Against Labor Demand in the Food Beverage and Tobacco Industry, North Sumatra Province}

Variable RMW turns out to have a negative and significant relationship to the demand for labor in the food, beverage and tobacco sector in North Sumatra Province. This is in accordance with the initial hypothesis of the study.

The decline in demand for labor in the food, beverage and tobacco sector in North Sumatra was due to changes in the increase in the RMW. The results of this study reveal that every 1 percent increase in the minimum wage rate will reduce the amount of labor demand in the food, beverage and tobacco sector industries in North Sumatra by 0.0977 percent.

The results of this study support the results of previous research, Karo-karo (2009: 84) who conducted a study entitled "Analysis of the Labor Market in North Sumatra". The results of this study indicate that wages have a negative effect on labor demand in North Sumatra. Furthermore, Rachman (2005: 76) in his study of job opportunities in DKI Jakarta found that the provincial minimum wage had a negative effect on job opportunities.

Not only that, Prihartanti (2007: 89) in his research on "Factors that influence employment in the industrial sector in the city of Bogor. The results of this study indicate that wages give negative results on employment in the industrial sector in Bogor City. " The results of this study also support previous research, Luthfi (2011: 74) conducted a study entitled "Analysis of Determinants of Job Opportunities in the Industrial Sector in 
North Sumatra". The results of this study indicate that the minimum wage has a negative effect on employment opportunities in North Sumatra.

The results of this study confirm that wages have a negative and significant effect on the demand for labor in the food, beverage and tobacco sector in Prov. North Sumatra. The increase in wages each year is inversely proportional to the real demand for labor in the food, beverage and tobacco sector each year. It is understandable that an increase in employee wages will certainly increase industrial production costs, increase production costs, increase employee wages and decrease industrial profits, of course, will create a dilemma for industry players who are often forced to reduce the number of workers in order to optimize profits.

Therefore, the results of this study indicate that the higher the wage level of an area, the lower the demand for labor in the food, beverage and tobacco sector in North Sumatra Province.

Variable Industrial Sector Investment, Number of Food Beverage and Tobacco Industry, Inflation and RMW Against Labor Demand in the Food Beverage and Tobacco Industry, North Sumatra Province

Simultaneously, variable investment in the industrial sector, the number of food and beverage and tobacco industries, inflation and RMW have a significant effect on the demand for labor in the food and beverage and tobacco industry in North Sumatra Province.

In addition, it turns out that the investment variables in the industrial sector, the number of food and beverage and tobacco industries, inflation and the UMR are able to explain the model of labor demand in the food, beverage and tobacco industry in North Sumatra Province by 77.81 percent. And the remaining 22.19 percent is influenced by other variables not examined in this study.

\section{CONCLUSIONS AND RECOMMENDATIONS}

\section{Conclusion}

1. Simultaneously, the investment variable in the industrial sector and RMW has a significant effect on the demand for labor in the food, beverage and tobacco industry in North Sumatra Province.

2. Partially it is concluded that the industrial sector investment variable and the number of industries have a positive and significant effect, RMW variable has a negative and significant effect, while the inflation variable has a negative and insignificant effect on labor demand in the food, beverage and tobacco industry sectors in North Sumatra Province.

3. The industrial sector investment variables, the number of industries, RMW, and inflation are able to explain the model of labor demand in the food, beverage and tobacco industry sector in North Sumatra Province by 77.81 percent. And the remaining 22.19 percent is influenced by other variables. 
4. The results of this study also indicate that the variable that most dominantly influences the demand for labor in the food, beverage and tobacco industry sector in the province of North Sumatra is RMW.

\section{Suggestion}

1. The government is expected to increase RMW so that people can meet their needs.

2. The government cooperates with Bank Indonesia in controlling the rate of inflation by adding Regional Inflation Monitoring and Supervision team at the sub-district / sub-district level.

3. Apart from investment in the industrial sector, the number of industries, RMW, and inflation, there are other factors related to labor demand such as credit interest rates, real GDP and others that may be used as additional variables for further research.

\section{REFERENCES}

Badan Pusat Statistik (BPS). Sumatera Utara Dalam Angka. Tahun 2001 - 2010.

Donna, Ainil. 2011. Pengaruh Pertumbuhan Ekonomi, Investasi, Upah Minimum Provinsi Dan Krisis Ekonomi Terhadap Kesempatan Kerja Di Sumatera Utara. Tesis. Medan : Program Pascasarjana Universitas Sumatera Utara.

Dumairy. 2001. Perekonomian Indonesia. Cetakan Kelima. Penerbit Erlangga. Jakarta.

Gujarati, Damodar N. 2006. Ekonometrika Dasar. Jakarta : Erlangga.

Lubis, Mitra Mustika. 2010. Analisis Faktor-Faktor Yang Mempengaruhi Penyerapan Tenaga Kerja Sektor Pertanian Di Sumatera Utara Tesis. Medan : Program Pascasarjana Universitas Sumatera Utara.

Karo-karo, Berla. 2009. Analisis Pasar Tenaga Kerja di Sumatera Utara. Tesis. Medan : Program Pascasarjana Universitas Sumatera Utara.

Kuncoro. 2001. Analisis Spasial dan Regional: Aglomerasi dan Kluster Industri Indonesia. Yogjakarta : LAMP YKPN.

Luthfi, Muhammad Idris. 2011. Analisis Determinan Kesempatan Kerja Sektor Industri Di Sumatera Utara. Tesis. Medan : Program Pascasarjana Universitas Sumatera Utara.

Mulyadi, S. 2003. Ekonomi Sumber Daya Manusia. Dalam Perspektif Pembangunan. Cetakan Kedua.. Jakarta : Raja Grafindo Persada.

Prihartanti. 2007. Faktor- Faktor Yang Mempengaruhi Penyerapan Tenaga Kerja Sektor Industri di Kota Bogor. Tesis. Bogor : Institut Pertanian Bogor.

Siringo Ringo, Rimmar. 2007. Analisis Faktor-faktor yang Memoengaruhi Kesempatan Kerja pada Industri Menengah dan Besar di Provinsi Sumatera Utara. Tesis diterbitkan. Medan: Program Pascasarjana Universitas Sumatera Utara.

Sudarsono, 2005. Pengantar Ekonomi Mikro. Jakarta: LP3ES

QE Journal | Vol.09 - No.02 - 64 
Sukirno, Sadono. 2000. Makro Ekonomi, Teori Pengantar. Edisi Ketiga. Jakarta. RajaGrafindo Persada.

Sumarsono. 2003. Perekonomian Indonesia: Teori dan Temuan Empiris. Jakarta: Ghalia Indonesia.

Tambunan, Tulus. 2001. Industrialisasi Negara Berkembang. Jakarta : Ghalia Indonesia.

Todaro. P. Michael. 2000. Pembangunan Ekonomi di Dunia Ketiga, Jakarta: Erlangga

Waluyo, Dwi E. 2003. Ekonomi Makro. Edisi Revisi. Malang.

Winarno, Wing Wahyu. 2007. Analisis Ekonometrika dan Statistika dengan Eviews. Jogjakarta : UPP STIM YKPN. 